\title{
Evaluation of transfection methods for transient gene expression in Chinese hamster ovary cells
}

\author{
Si Nga Sou ${ }^{1,2,3}$, Karen M. Polizzi ${ }^{1,2}$, Cleo Kontoravdi ${ }^{3 *}$ \\ ${ }^{1}$ Department of Life Sciences, Imperial College London, London, UK \\ ${ }^{2}$ Centre for Synthetic Biology and Innovation, Imperial College London, London, UK \\ ${ }^{3}$ Centre for Process Systems Engineering, Department of Chemical Engineering, Imperial College London, London, UK \\ Email: ${ }^{*}$ cleo.kontoravdi@imperial.ac.uk
}

Received 27 August 2013; revised 1 October 2013; accepted 25 October 2013

Copyright (C) 2013 Si Nga Sou et al. This is an open access article distributed under the Creative Commons Attribution License, which permits unrestricted use, distribution, and reproduction in any medium, provided the original work is properly cited.

\begin{abstract}
Three transfection reagents, Lipofectamine ${ }^{\circledR}$ 2000, TransIT-PRO $^{\circledR}$ and linear $25 \mathrm{kDa}$ polyethylenimine were evaluated for transient expression of enhanced green fluorescent protein in Chinese hamster ovary cells. TransIT-PRO ${ }^{\circledR}$ was found to be more efficient under the examined conditions, but comes at an increased cost compared to the widely used PEI.
\end{abstract}

Keywords: Transient Gene Expression; Transfection Efficiency; Chinese Hamster Ovary Cells; mRNA

Stability; Temperature Shift

\section{INTRODUCTION}

Transient gene expression (TGE) is capable of producing recombinant proteins (rProteins) faster and cheaper than the standard stable cell line development process, making it an attractive alternative for the provision of material for preclinical trials and toxicological studies [1]. Chinese hamster ovary (CHO) cells are a typical mammalian host for TGE; however the main obstacle of this approach is the low protein yield. Research has therefore focused on ways to improve rProtein productivity through TGE optimization, including examining the transfection efficiency of foreign DNA plasmids into cells of different cell lines, determining the best transfection method/reagent for each cell type, and exploring effects of culture parameters.

There are several chemical transfection reagents, e.g. polyethylenimine (PEI), Lipofectamine ${ }^{\circledR} 2000$ (Invitrogen, UK), and TransIT-PRO ${ }^{\circledR}$ (Mirus Bio LLC, US). Of these, PEI is commonly used at large scale [1] because it provides efficient transfection $(40 \%-90 \%)$ in most cell lines and is cost-effective [2,3]. PEI works by forming

${ }^{*}$ Corresponding author. polyplexes with target DNA. These positively charged polyplexes interact with the negatively charged host cell membrane and release DNA into the cell. Addition of sodium chloride $(\mathrm{NaCl})$ increases the culture osmolality, which aids DNA delivery [4]. Lipofectamine ${ }^{\circledR} 2000$ is a cation-lipid formulation transfection reagent that forms liposomes in aqueous media. DNA is enclosed within the liposomes and the complexes fuse with the host cell membrane for DNA entry into the cytoplasm and eventually into the nucleus. Serum-free medium is necessary for successful DNA-Lipofectamine ${ }^{\circledR} 2000$ complex formation. Although Lipofectamine ${ }^{\circledR} 2000$ is compatible with most cell lines, the transfection efficiency cannot be sustained in prolonged high cell density culture for largescale operation [1]. TransIT-PRO ${ }^{\circledR}$ employs both mechanisms of action and works by forming lipopolyplexes with DNA, which then forms electrostatic interactions with the negatively charged cell membrane. These lipopolyplexes are believed to be taken into the cell via endocytosis. The use of this reagent involves an optional proprietary transfection booster PRO Boost, which was shown to enhance gene expression in a medium-dependent manner.

Optimisation of the reagent/DNA ratio and process conditions is of paramount importance to achieve high transfection efficiency while limiting side effects. Toxicity of transfection reagents is of particular concern in TGE systems. Previous studies suggest that liposomal transfection reagents are more detrimental to cells than lipid- or polyamine-based reagents [5]. TransIT-PRO ${ }^{\circledR}$ is also reported to have high compatibility with multiple cell types and culture media [6].

Additionally, mild hypothermia (a shift to $32^{\circ} \mathrm{C}$ posttransfection) has been demonstrated to increase rProtein yield although efficiency varies among different expression vectors [7]. The mild cold-stress is believed to help stabilize and increase the mRNA content, and improve 
mRNA translation and protein folding with an up-regulation in chaperone expression.

In this study, we compare PEI, Lipofectamine ${ }^{\circledR} 2000$ and TransIT-PRO ${ }^{\circledR}$ for the transient expression of the enhanced green fluorescent protein (EGFP) in suspension-adapted CHO-S cells. The comparison is based on the impact of each reagent on cell growth, DNA uptake, mRNA and protein production.

\section{MATERIALS AND METHODS}

\subsection{Cell Culture}

Prior to transfection, the CHO-S cells (Invitrogen, UK) were routinely maintained in CD-CHO medium supplemented with $8 \mathrm{mM}$ glutamine and $10 \mathrm{~mL} / \mathrm{L}$ hypoxanthine/thymidine supplement (all from Invitrogen, UK), shaken at $140 \mathrm{rpm}$ in a humidified $37^{\circ} \mathrm{C}$ incubator in $8 \%$ $\mathrm{CO}_{2}$. Cell concentration and viability were measured using the trypan blue dye exclusion method.

\subsection{DNA Plasmid}

The pEGFP-C3 plasmid DNA (Clontech Laboratories, CA) was first propagated in E. coli $\mathrm{DH} 5 \alpha$ and purified by the QIAprep ${ }^{\mathbb{R}}$ Spin Miniprep Kit (Qiagen, UK) according to the manufacturer's instructions.

\subsection{Transient Transfection Methods}

\subsubsection{Transfection Reagent Ratio Optimisation in CHO-S Cells}

The ratios of transfection reagent to DNA examined are listed in Table S1 (Supplementary material). For Linear PEI 25,000 Da (Polysciences Europe GmbH, Germany) the protocol is as follows (based on [8]): $0.8 \mu \mathrm{L}$ of DNA and varying amounts of PEI (Table S1) were diluted in separate tubes containing $8.31 \mu \mathrm{L}$ of $150 \mathrm{mM} \mathrm{NaCl}$, mixed and incubated at room temperature for 2 min prior to addition to the cell suspension in $\mathrm{CD}-\mathrm{CHO}$ medium $(16.62 \mu \mathrm{L}$ of complex in $500 \mu \mathrm{l}$ of cells). For Lipofectamine ${ }^{\circledR} 2000$ (Invitrogen, UK), the DNA and various amounts of Lipofectamine ${ }^{\circledR} 2000$ (Table S1) were each diluted separately in $50 \mu \mathrm{L}$ of Opti-MEM ${ }^{\circledR}$ I Reduced Serum Medium (Invitrogen, UK), mixed and incubated at room temperature for $5 \mathrm{~min}$. The diluted DNA and Lipofectamine ${ }^{\circledR} 2000$ were combined and incubated at room temperature for $20 \mathrm{~min}$ before addition to the cells. For the TransIT-PRO ${ }^{\circledR}$ transfection, TransIT-PRO ${ }^{\circledR}$ and PRO Boost reagents (both Mirus Bio LLC, US) were pre-warmed to room temperature. The TransIT-PRO ${ }^{\circledR}$, DNA and PRO Boost complex was formed by adding appropriate amounts of each reagent into DNA that was diluted in $100 \mu \mathrm{L} \mathrm{CD-CHO} \mathrm{medium} \mathrm{(Table} \mathrm{S1).} \mathrm{Com-}$ plexes were incubated at room temperature for $30 \mathrm{~min}$ prior to addition to the cell suspension. In all cases triplicate samples and negative controls were examined.
Transfection efficiency by each reagent was determined via the fluorescent emission of EGFP protein expressed by the cells upon DNA uptake. EGFP has a maximum excitation wavelength of $488 \mathrm{~nm}$ (filter bandwidth 465 $+/-35 \mathrm{~nm}$ ) and a maximum emission of $507 \mathrm{~nm}$ (filter bandwidth $510+/-10 \mathrm{~nm}$ ). Fluorescent intensity was detected by the Infinite 200Pro microplate reader (Tecan Group Ltd, UK) every $2 \mathrm{~h}$ for 14 days, with a gain value of 100 .

\subsubsection{Transient Gene Expression in an Automated Cell Culture Environment}

Subsequently, an assessment of the overall transfection characteristics of these reagents was carried out in a 48-well plate BioLector ${ }^{\circledR}$ (m2p-labs GmbH, Germany) in $1.5 \mathrm{~mL}$ of cell suspension at $37^{\circ} \mathrm{C}$ and with a temperature shift to $32^{\circ} \mathrm{C}$ induced $24 \mathrm{~h}$ post-transfection. Scaling up from the transfection protocols described above, $4 \mu \mathrm{g}$ of DNA was transfected using each of the three reagents at their respective optimal ratio. Cells were incubated in a humidified $8 \% \mathrm{CO}_{2}$ atmosphere at $37^{\circ} \mathrm{C}$ rotating at 800 rpm. Fluorescence measurements (excitation: $488 \mathrm{~nm}$, emission: $510 \mathrm{~nm}$ ) were taken every 60 min using a gain value of 60 until the peak fluorescence was observed. Cell density and viability were determined daily by the trypan blue dye exclusion method using light microscopy. Total DNA and RNA were extracted from cell pellets using the AllPrep ${ }^{\circledR}$ DNA/RNA mini purification kit (Qiagen, UK).

\section{4. cDNA Preparation and Real-Time Polymerase Chain Reaction (qRTPCR)}

To estimate the DNA and mRNA copy number, cDNA synthesis and real-time polymerase chain reaction (qRTPCR) were used as follows: $250 \mathrm{ng}$ of mRNA from each sample was reverse transcribed into cDNA using 1 $\mu \mathrm{L}$ of the RT Primer Mix of the QuantiTect ${ }^{\circledR}$ Reverse Transcription Kit (Qiagen, UK). Levels of EGFP mRNA/ DNA in each sample were quantified by qRTPCR in triplicate reactions. A total reaction volume of $10 \mu \mathrm{L}$ was used per sample on a 96-well plate, with $5 \mu \mathrm{L}$ of $2 \times$ SYBR $^{\circledR}$ Green JumpStart ${ }^{\mathrm{TM}}$ Taq ReadyMix ${ }^{\mathrm{TM}}$ (Sigma Aldrich, UK), $0.7 \mathrm{ng}$ DNA or $0.2 \mu \mathrm{L}$ of cDNA and 500 $\mathrm{nM}$ of each primer with the following pEGFP-C3 primer sequences:

- pEGFP-C3 (Forward)

5'-GGCGATGCCACCTACGGCAA-3'

- pEGFP-C3 (Reverse)

5'-CATGTGGTCGGGGTAGCGGC-3'

Non-template controls were carried out in each reaction. PCR reactions were initiated with 3 min activation at $95^{\circ} \mathrm{C}$; followed by 40 cycles of $95^{\circ} \mathrm{C}$ for $30 \mathrm{~s}$, $60^{\circ} \mathrm{C}$ for $75 \mathrm{~s}$ and $72^{\circ} \mathrm{C}$ for $30 \mathrm{~s}$. The product integrity was verified by DNA melting curve analysis $\left(65^{\circ} \mathrm{C}-\right.$ $95^{\circ} \mathrm{C}$, every $0.3^{\circ} \mathrm{C}$ ). Results were normalized to a stan- 
dard curve with a known amount of plasmid vector.

\section{RESULTS AND DISCUSSION}

\subsection{Evaluation of pEGFP-C3 DNA:Transfection Reagent Ratio in CHO-S Cells}

The optimal DNA:reagent ratio was first identified for each of the three systems to limit side effects due to reagent cytotoxicity. From the results (Figure S1), we concluded that a 1:2 DNA:Lipofectamine ${ }^{\circledR} 2000$ ratio gave a better distribution of EGFP-C3 expression, with an exponential increase of EGFP fluorescence and a maximum protein expression at 200 hours (Figure S1(a)). In the case of PEI (Figure S1(b)), a 1:4 DNA:PEI ratio resulted in the highest levels of fluorescence, while DNA:PEI ratios above 1:5 showed very low protein expression levels. This is in contrast with Xie et al. [9] who suggested that a higher PEI concentration assisted DNA delivery into the cell nucleus and recommended a 1:5 ratio for an EGFP vector transfected into CHO-DG44 cells. The TransIT-PRO ${ }^{\circledR}$ transfection method required two reagents, TransIT-PRO ${ }^{\circledR}$ \& PRO Boost. The results (Figure S1(c)) suggested that TransIT-PRO ${ }^{\circledR}$ :DNA:PROBoost ratio of 1:1:1 achieves the highest EGFP protein expression.

\subsection{Growth Profile of pEGFP-C3 Transfected CHO-S Cells in TGE}

Figure 1 shows the growth and viability profiles of the transfectants. At $37^{\circ} \mathrm{C}$, Lipofectamine ${ }^{\circledR} 2000$-transfected cells have a rising trend in their viable cell density, while cells treated with PEI and TransIT-PRO ${ }^{\circledR}$ showed reductions in viable cell concentrations on day 2, but these later recovered (Figure 1(a)). On day 8, PEI-treated cells had the highest viable cell density with $91 \%$ viability, while TransIT-PRO ${ }^{\circledR}$-and Lipofectamine ${ }^{\circledR} 2000$ treated cells had viabilities of $78 \%$ and $74 \%$, respectively.

At $32^{\circ} \mathrm{C}$, cell viability in the presence of Lipofectamine ${ }^{\circledR} 2000$ remained relatively high and was maintained at $96 \%$ until the end of the experiment (Figure 1(b)). For the TransIT-PRO ${ }^{\circledR}$ transfectants, viable cell density fluctuated between 4.5 and $6 \times 10^{5}$ cells $/ \mathrm{mL}$ and $60 \%$ cell viability was achieved on day 8 . PEI-treated cells had a declining trend in their growth throughout the culture period and a dramatic decrease in the viable cell density was observed on day 2 . This is most likely due to the high toxicity of PEI, which, when combined with mild hypothermia, prevented the cells from recovering from the transfection process. This is in contrast to Wulhfard et al. [10] who achieved $80 \%$ viability when mild hypothermia of $31^{\circ} \mathrm{C}$ was induced $4 \mathrm{~h}$ post transfection. It is therefore possible that viability could be improved by optimizing the timing of the temperature

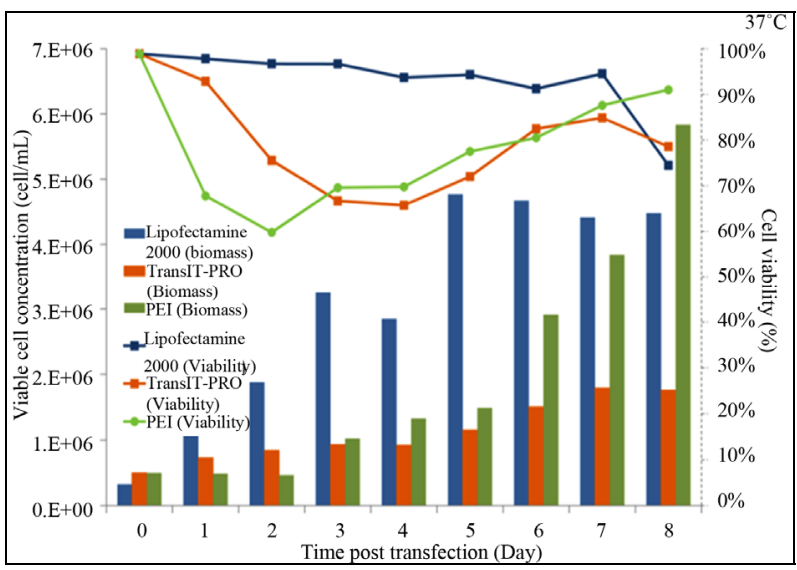

(a)

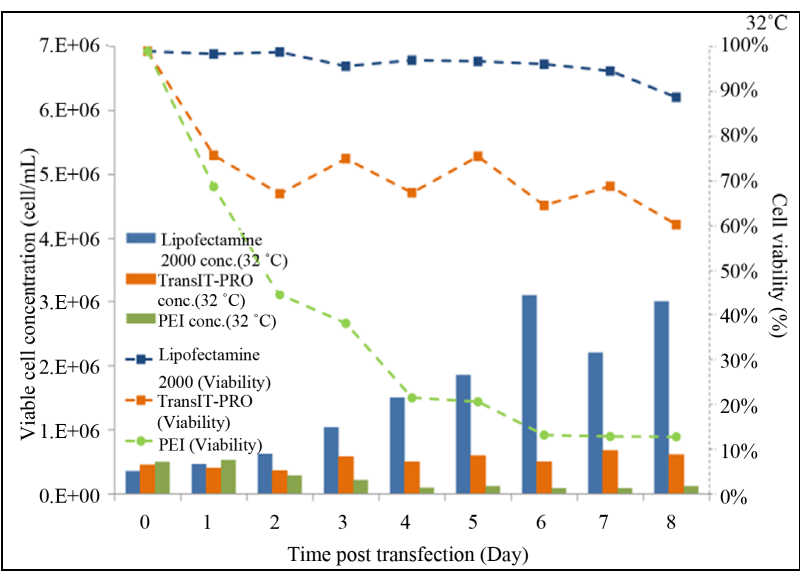

(b)

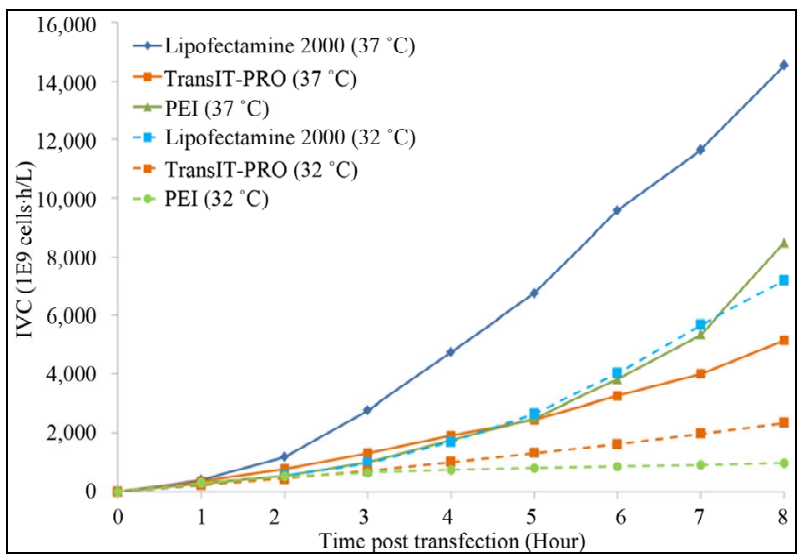

(c)

Figure 1. Growth profiles of CHO-S cells transfected with the Lipofectamine $^{\circledR} 2000$, PEI and TransIT-PRO ${ }^{\circledR}$. (a) Cell growth and viability profile of $\mathrm{CHO}-\mathrm{S}$ transfected at $37^{\circ} \mathrm{C}$ (Bar: cell density, dotted line: viability); (b) Cell growth and viability profile of CHO-S transfected with a temperature shift to $32^{\circ} \mathrm{C}$ $24 \mathrm{~h}$ post-transfection (Bar: cell density, dotted line: viability); (c) IVCC profiles of transfected cells maintained at $37^{\circ} \mathrm{C}$ (solid lines) and $32^{\circ} \mathrm{C}$ (dotted lines).

shift. Cells maintained at $37^{\circ} \mathrm{C}$ had a higher integral viable cell concentration (IVCC) with all transfection 
methods when compared to cells that were switched to $32^{\circ} \mathrm{C}$ (Figure 1(c)).

\subsection{EGFP-C3 DNA, RNA and Protein Expression in CHO-S Cells in TGE}

Figure 2(a) shows the pEGFP-C3 DNA copy number per cell for each transfection reagent. At $37^{\circ} \mathrm{C}$, cells had their highest DNA uptake during lag phase in all methods examined. TransIT-PRO ${ }^{\circledR}$ and PEI had 3.8- and 3.4-fold more DNA uptake than Lipofectamine ${ }^{\circledR} 2000$, respectively. Transfection by TransIT-PRO ${ }^{\circledR}$ achieved the highest total DNA uptake, 8 and 2.7 times higher than that for Lipofectamine ${ }^{\circledR} 2000$ and PEI, respectively.

With mild hypothermia, peak DNA uptake shifted to the late exponential to stationary phase for Lipofectamine $^{\circledR} 2000$ and TransIT-PRO ${ }^{\circledR}$, whereas PEI-treated cells remained similar to those at $37^{\circ} \mathrm{C}$. The total DNA copy number per cell observed was higher at $32^{\circ} \mathrm{C}$ than $37^{\circ} \mathrm{C}$. Of all methods, TransIT-PRO ${ }^{\circledR}$ had the highest DNA uptake suggesting that this reagent resulted in the highest transfection efficiency. Additionally, it can be concluded that mild hypothermia achieves increased DNA uptake with a delay in the timing of uptake.

The mRNA copy number per cell shares a similar profile to the DNA uptake in the TransIT-PRO ${ }^{\circledR}$ and the PEI methods at $37^{\circ} \mathrm{C}$ (Figure 2(b)). However, a minimal amount of EFGP mRNA was detected with Lipofectamine $^{\circledR} 2000$, despite a fair amount of DNA uptake. mRNA production was highest in TransIT-PRO ${ }^{\circledR}$-treated cells, 21.6 times and 5.2 times higher than those with Lipofectamine $^{\circledR} 2000$ and PEI, respectively, but dropped significantly after day 4 . At $32^{\circ} \mathrm{C}$, the mRNA copy number observed in Lipofectamine ${ }^{\circledR} 2000$ transfectants remained low, whereas for the other two reagents it was increased. There was a drop in mRNA concentration on day 3 in all cases, likely due to the adaptation of cells upon temperature shift. The TransIT-PRO ${ }^{\circledR}$ method had a similar number of mRNA copies during lag phase, but a significant rise in mRNA production in the late exponential phase at $32^{\circ} \mathrm{C}$ (Figure 2(b)). In contrast, PEItreated cells achieved a 4-fold increase in mRNA level at $32^{\circ} \mathrm{C}$ on day 2 , but the amount reduced considerably afterwards. The total mRNA production at $32^{\circ} \mathrm{C}$ was higher than at $37^{\circ} \mathrm{C}$ in the TransIT-PRO ${ }^{\circledR}$ and the PEI transfectants, but was 6 times lower in Lipofectamine ${ }^{\circledR}$ 2000-treated cells.

EGFP protein expression levels were quantified through fluorescence intensity and results are displayed in Figure 3. At $37^{\circ} \mathrm{C}$, TransIT-PRO ${ }^{\circledR}$-treated cells reached a maximum fluorescence at 109 hours (day 4), PEI-treated cells at 115 hours (day 4) and Lipofectamine ${ }^{\circledR} 2000$ at 85 hours (Figure 3(a)). The TransIT-PRO ${ }^{\circledR}$ method exhibited 7.9 and 2.8 times higher maximum fluorescence

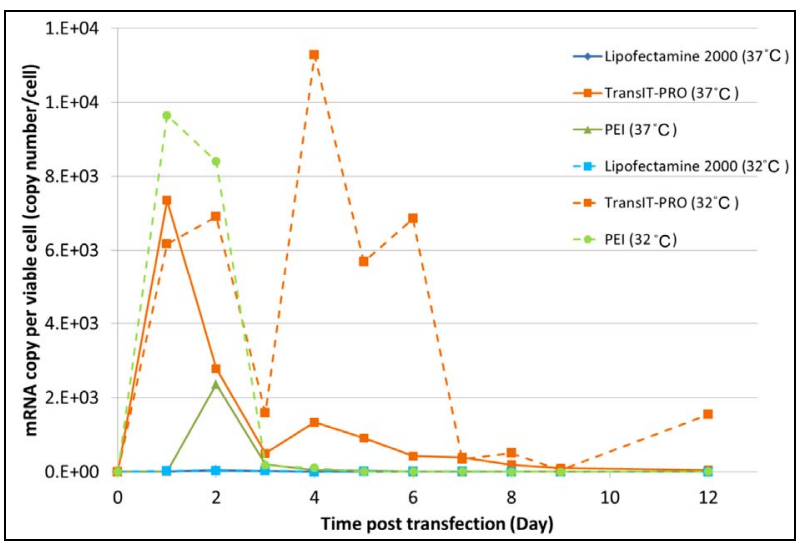

(a)

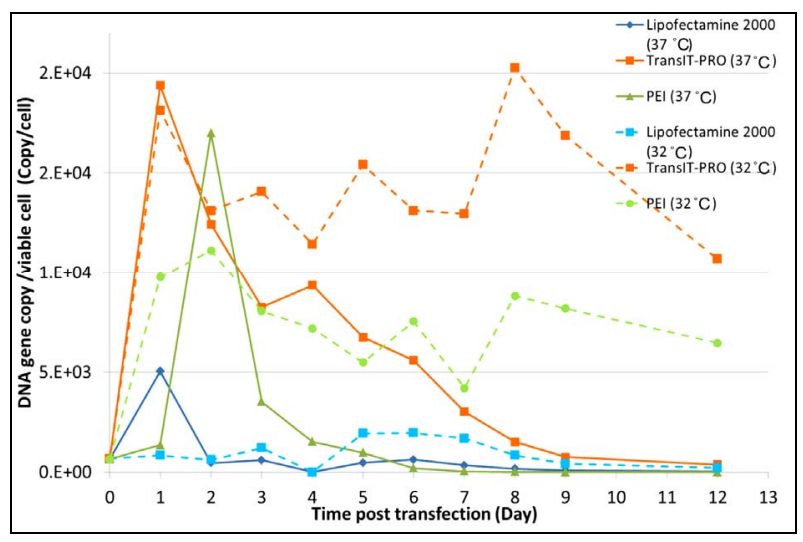

(b)

Figure 2. Evaluation of (a) the intracellular pegfp-c3 dna level and (b) the intracellular EGFP-C3 mRNA copy number upon transient transfection with different reagents.

levels than the Lipofectamine ${ }^{\circledR} 2000$ and PEI methods, respectively. However, an exponential decrease in protein expression was observed after the peak in all cases, which is in agreement with the lower number of mRNA copies after day 4 at $37^{\circ} \mathrm{C}$ (Figure 2(b)). Under mild hypothermia, TransIT-PRO ${ }^{\circledR}$ transfectants had peak fluorescence at 205 hours (day 8), and the protein level remained high (Figure 3(b)). Cells transfected with PEI and Lipofectamine ${ }^{\circledR} 2000$ showed decreased levels of total fluorescence at $32^{\circ} \mathrm{C}$. However, Figure 3(c) shows that the estimate of specific productivity based on fluorescence per $1 \times 10^{5}$ viable cells was higher at $32^{\circ} \mathrm{C}$ than at $37^{\circ} \mathrm{C}$ due to the lower IVCC achieved under hypothermia. Consistent with the DNA and mRNA copy numbers, TransIT-PRO ${ }^{\circledR}$ transfection resulted in a higher protein expression than the other two methods, with 2.0and 1.8-fold higher specific productivity when compared to PEI-treated cells (the next highest) at $37^{\circ} \mathrm{C}$ and $32^{\circ} \mathrm{C}$, respectively. Despite the simple structure of EGFP, our results are consistent with previous studies that show increased mRNA and protein stability under mild hypothermia [11]. 


\section{CONCLUSIONS}

Overall, our results show that TransIT-PRO ${ }^{\circledR}$ outperformed the other reagents at both temperatures. It was

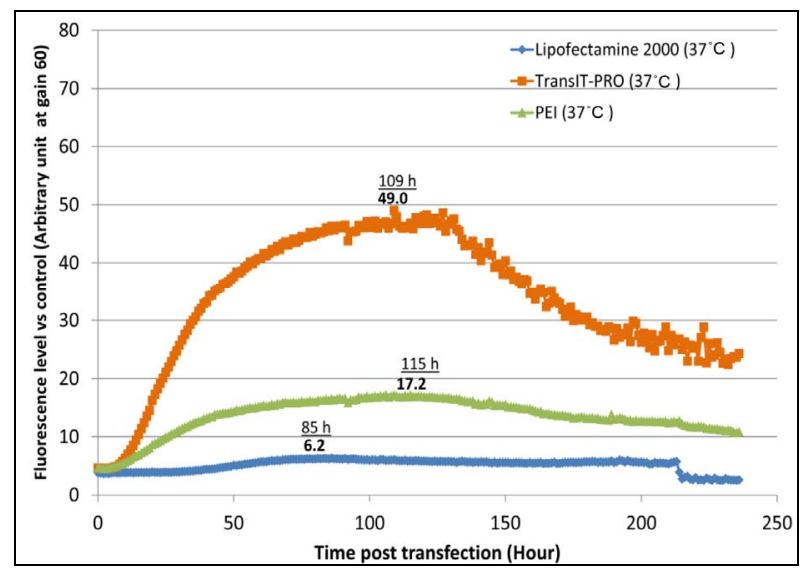

(a)

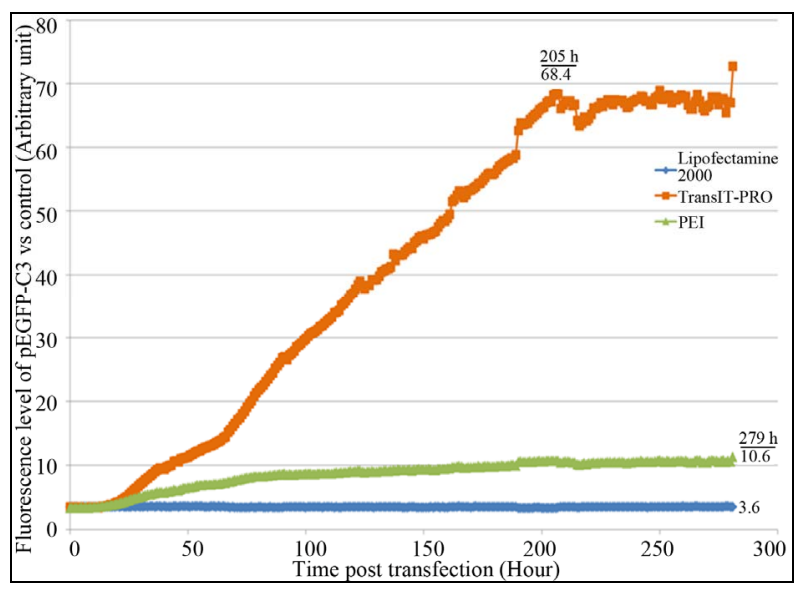

(b)

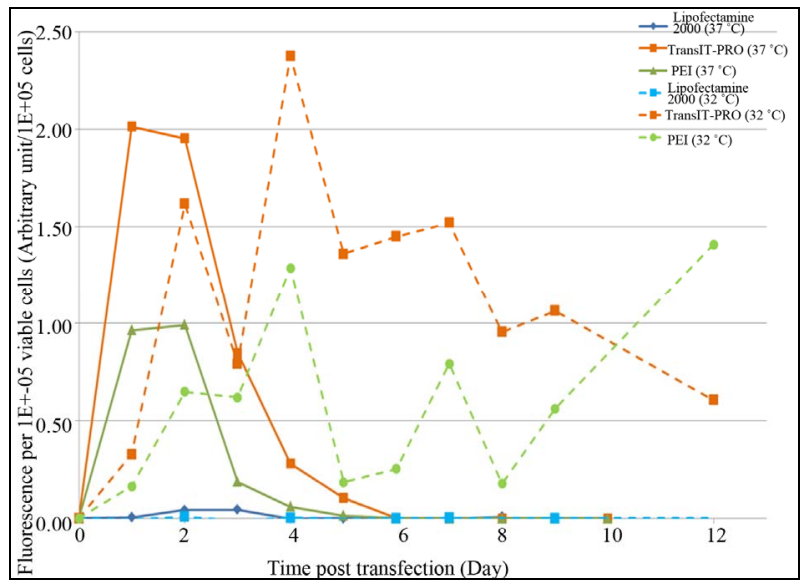

(c)

Figure 3. Evaluation of EGFP-C3 protein expression level upon transient transfection with different reagents. (a) EGFP$\mathrm{C} 3$ protein expression at $37^{\circ} \mathrm{C}$; (b) EGFP-C3 protein expression at $32^{\circ} \mathrm{C}$; (c) EGFP-C3 protein expression per viable cell at $37^{\circ} \mathrm{C}$ $\& 32^{\circ} \mathrm{C}$. shown to be less toxic than PEI and yielded improved DNA uptake, mRNA copy number and rProtein production levels. Lipofectamine ${ }^{\circledR} 2000$ affected cell growth the least, but achieved poor transfection efficiency under the conditions examined. PEI, despite being toxic to the cells, achieved a high number of mRNA copies per viable cell and higher rProtein titre than Lipofectamine ${ }^{\circledR} 2000$ at $37^{\circ} \mathrm{C}$. This titre was, however, reduced at $32^{\circ} \mathrm{C}$ because, even though DNA uptake was improved and mRNA copies were higher, in this study, the cells did not recover from the combination of reagent toxicity and mild hypothermia.

The use of EGFP protein with a relatively simple structure (single polypeptide chain vs 4 polypeptides chain in monoclonal antibodies) does not allow us to draw generic conclusions regarding the effect of a temperature shift on rProtein productivity. Mild hypothermia has been suggested to aid protein folding and expression of rProteins with more complex structures and could benefit more from it [12]. In addition to the transfection efficiency of each reagent, the overall manufacturing cost of cell culture is also a crucial factor to determine which transfection method is more cost effective. Of the three transfection reagents examined and with the efficiency obtained in this study, the cost of the Lipofectamine ${ }^{\circledR}$ 2000 reagent would be the highest at a $1 \mathrm{~L}$ bioreactor scale, followed by TransIT-PRO ${ }^{\circledR}$ and then PEI. However, the yield of EGFP protein from TransIT-PRO ${ }^{\circledR}$ would be higher than those from the other two methods. Therefore, in order to produce the same amount of EGFP protein the material cost of using TransIT-PRO ${ }^{\circledR}$ was estimated to be approximately $64 \%$ and $87 \%$ lower than using $25 \mathrm{kDa}$ linear PEI and Lipofectamine ${ }^{\circledR} 2000$, respectively. These promising results for the use of TransIT-PRO ${ }^{\circledR}$ for transient gene expression, however, require further evaluation based on optimized protocols for other protein products, especially secreted proteins.

\section{ACKNOWLEDGEMENTS}

SNS thankfully acknowledges the Biotechnology and Biological Sciences Research Council for her studentship. The financial contribution of MedImmune plc is gratefully acknowledged. KMP and CK thank Research Councils UK for their fellowships. CK thanks Lonza Biologics for their financial support.

\section{REFERENCES}

[1] Codamo, J., Munro, T.P., Hughes, B.S., Song, M. and Gray, P.P. (2011) Enhanced CHO cell-based transient gene expression with the Epi-CHO expression system. Molecular Biotechnology, 48, 109-115.

[2] Morrow, K.J. (2008) Optimizing transient gene expression. Genetic Engineering \& Biotechnology News, 28, 54-59. 
[3] Ehrhardt, C., Schmolke, M., Matzke, A., Knoblauch, A., Will, C., Wixler, V. and Ludwig S. (2006) Polyethylenimine, a cost-effective transfection reagent. Signal Transduction, 6, 179-184. http://dx.doi.org/10.1002/sita.200500073

[4] Zaruc, V., Weltin, D., Erbacher, P., Remy, J.S., Behr, J.P. and Stephan, D. (2004) Effective polyethlenimine-mediated gene transfer into hunman endothelial cells. The Journal of Gene Medicine, 6, 176-184. http://dx.doi.org/10.1002/jgm.484

[5] Obata, Y., Ciofani, G., Raffa, V., Cuschieri, A., Menciassi, A., Dario, P. and Takeoka, S. (2010) Evaluation of cationic liposomes composed of an amino acid-based lipid for neuronal transfection. Nanomedicine: Nanotechnology, Biology and Medicine, 6, 70-77. http://dx.doi.org/10.1016/j.nano.2009.04.005

[6] Juckem, K.L. (2010) Maximize protein expression in $\mathrm{CHO}$ suspension cells. BioProcess International, 8, 122123.

[7] Galbraith, D.J., Tait, A.S., Racher, A.J., Birch, J.R. and James, D.C. (2006) Control of culture environment for improved polyethylenimine-mediated transient production of recombinant monoclonal antibodies by $\mathrm{CHO}$ cells. Biotechnology Progress, 22, 753-762. http://dx.doi.org/10.1021/bp050339v

[8] Thompson, B.C., Segarra, C.R.J., Mozley, O.L., Daramola, O., Field, R., Levison, P.R. and James, D.C.
(2012) Cell line specific control of polyethyleniminemediated transient transfection optimized with "Design of experiments" methodology. Biotechnology Progress, 28, 179-187. http://dx.doi.org/10.1002/btpr.715

[9] Xie, Q.L., Guo, X.Y., Chen, X.J. and Wang, Y.Y. (2013) $\mathrm{PEI} / \mathrm{DNA}$ formation affects transient gene expression in suspension Chinese hamster ovary cells via a one-step transfection process. Cytotechnology, 65, 263-271. http://dx.doi.org/10.1007/s10616-012-9483-9

[10] Wulhfard, S., Tissot, S., Bouchet, S., Cevey, J., De Jesus, M., Hacker, D.L. and Wurm, F.M. (2008) Mild hypothermia improves transient gene expression yields several fold in chinese hamster ovary cells. Biotechnology Progress, 24, 458-465. http://dx.doi.org/10.1021/bp070286c

[11] Roobol, A., Carden, M.J., Newsam, R.J. and Smales, C.M. (2009) Biochemical insights into the mechanisms central to the response of mammalian cells to cold stress and subsequent rewarming. FEBS Journal, 276, 286-302. http://dx.doi.org/10.1111/j.1742-4658.2008.06781.x

[12] Masterton, R.J., Roobol, A., Al-Fageeh, M.B., Carden, M.J. and Smales, C.M. (2010) Post translation events of a model reporter protein proceed with higher fidelity and accuracy upon mild hypothermic culturing of Chinese Hamster Ovary cells. Biotechnology and Bioengineering, 105, 215-220. http://dx.doi.org/10.1002/bit.22533 


\section{SUPPLEMENTARY MATERIALS}

Table S1. DNA:transfection reagent ratio used in the optimisation experiment for pEGFP-C3 transfection into CHO-S cells.

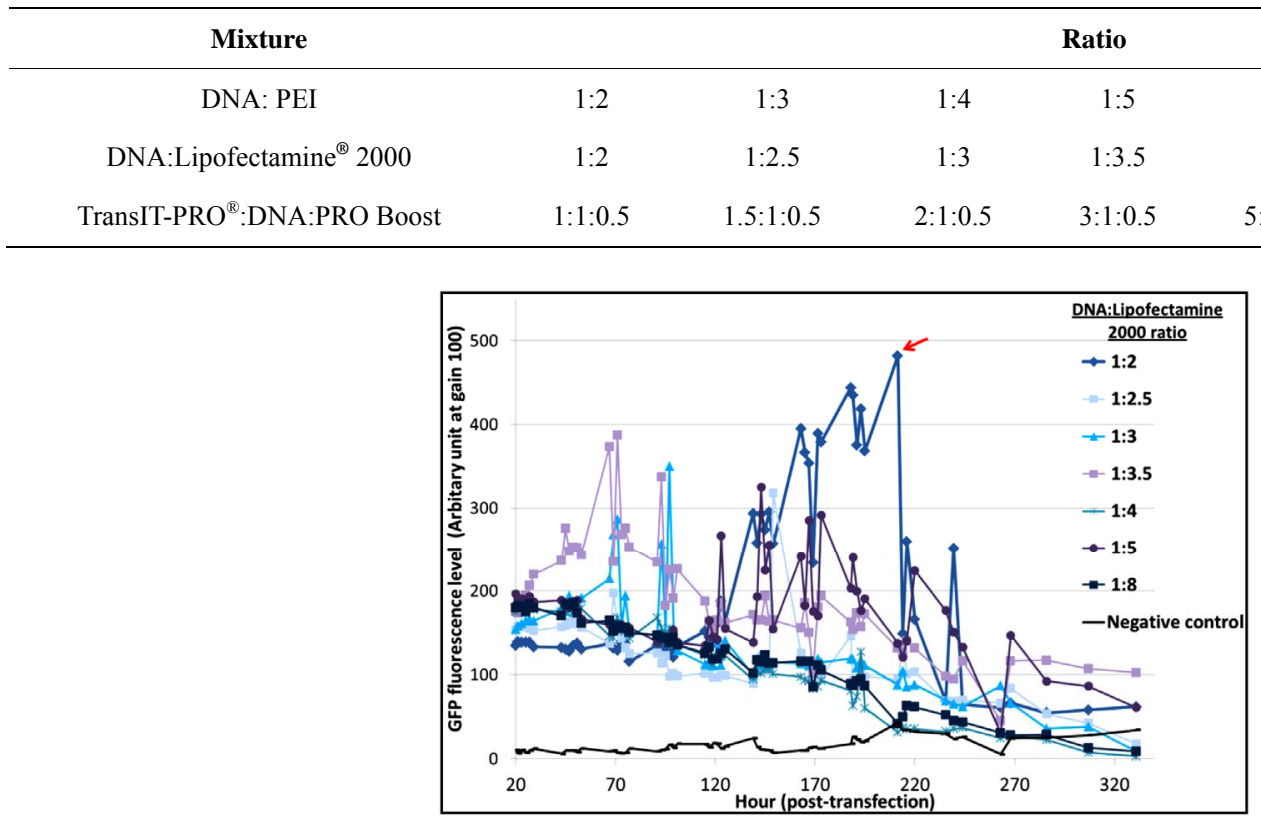

(a)

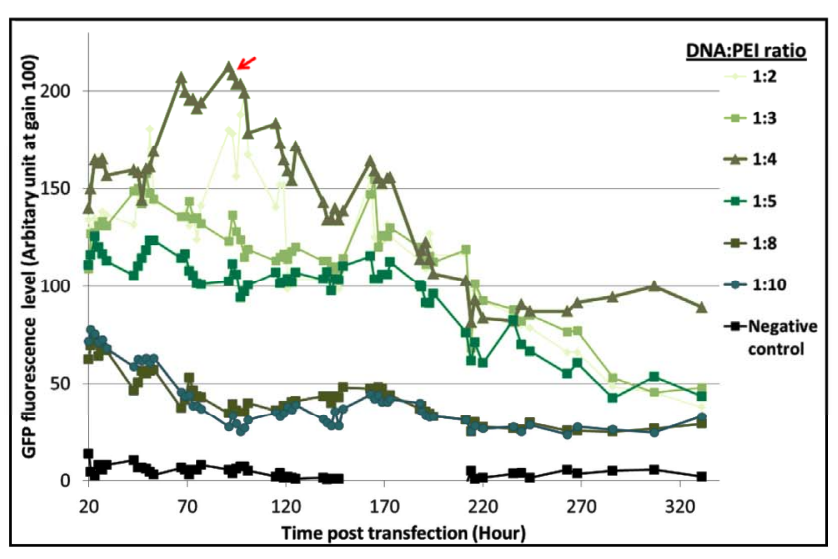

(b)

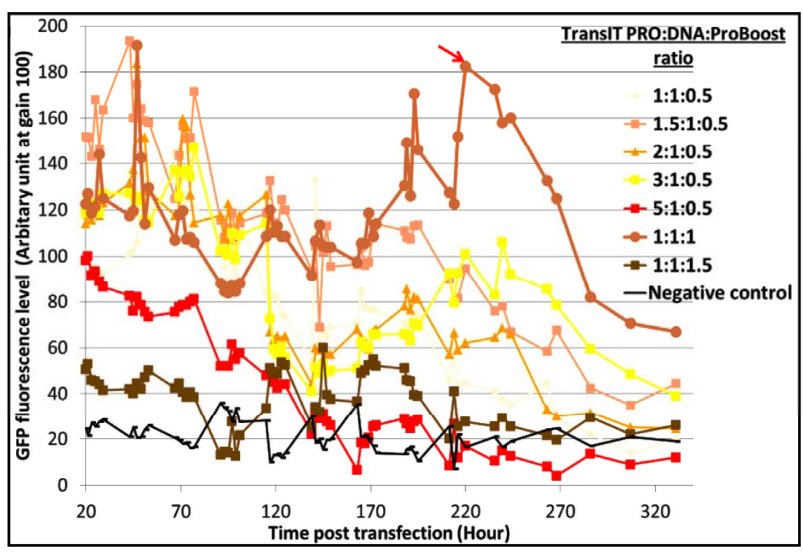

(c)

Figure S1. Evaluation of pEGFP-C3 DNA:transfection reagent ratios in CHO-S cells. (a) Lipofectamine ${ }^{\circledR} 2000$ transfection method. Seven different DNA:Lipofectamine ${ }^{\circledR} 2000$ ratios and a no DNA negative control were transfected into CHO-S cells and fluorescent intensities were measured; (b) PEI transfection method. Six different DNA:PEI ratios and a no DNA negative control were examined in CHO-S cells and the total fluorescence were measured; (c) TransIT-PRO ${ }^{\circledR}$ transfection method. Five different TransIT-PRO ${ }^{\circledR}$ concentrations with constant DNA and PRO Boost levels and constant levels of TransIT-PRO ${ }^{\circledR}$ \& DNA with 2 concentrations of PRO Boost, together with a no DNA negative control were examined in CHO-S cells and the total fluorescence were measured. 